\title{
PATHOGENIC FUNGAL CONTAMINATION OF MUNICIPAL DUMPING YARD, KOTTAYAM AND RELATED HEALTH EFFECTS
}

\author{
Vipinunni1 ${ }^{1}$ Bernaitis L2, Sabarianand ${ }^{3}$, Preesly M. $S^{4}$, Revathi P. Shenoy ${ }^{5}$ \\ ${ }^{1}$ Lecturer, RVS Dental College, Coimbatore. \\ ${ }^{2}$ Lecturer, RVS Dental College, Coimbatore. \\ ${ }^{3}$ Lecturer, Mahatma Gandhi Medical College, Pondicherry. \\ ${ }^{4}$ Lecturer, RVS Siddha Medical College \& Hospital, Coimbatore. \\ ${ }^{5}$ Associate Professor, Kasturba Medical College, Manipal.
}

ABSTRACT

\section{BACKGROUND}

Fungi are ubiquitous soil saprophytes often involved in various human ailments. Fungal diseases are emerging worldwide. However, the mycological health risks associated with dumping yard is not much investigated, especially from developing countries where such sites are very common.

Aims and Objectives- The major objective of the study was to analyse the possible mycological threat posed by the municipal dumping yard. The study also aims to assess the health status of interacting community in relation to the dumping yard.

\section{MATERIALS AND METHODS}

A descriptive study was conducted from April to June 2015 in Kottayam Municipal dumping yard at Vadavathoor. Two set of soil samples, a total of 50 from the dumping yard were collected, before and after burning of the dumping yard. One set of samples from leachate and neighbouring open wells were collected after burning of the dumping yard. Samples were collected in sterile containers and transported immediately to the laboratory. The samples were cultured on to suitable fungal culture medium and the growths of the fungus were identified by the microscopic and macroscopic features.

\section{RESULTS}

The isolated fungal pathogens from the soil shows that $49 \%$ isolates belonged to the Aspergillus genus; and the remaining $51 \%$ was almost equally shared by four other different species Geotrichum, Humicola, Microsporum, Rhizopus. Similar fungi isolated from the leachate in the dumping yard fetched six species with a higher prevalence of Aspergillus fumigates and Aspergillus nidulans. The mycological evaluation of the drinking water resources near to the dumping yard $(<100$ metre $)$ showed presence of twelve fungal pathogens with exceptionally high frequency of occurrence for Aspergillus fumigatus. The socioeconomic and health survey of the neighbouring community showed that $38.1 \%$ of the respondents have skin infections and $1.8 \%$ of them have cancer.

\section{CONCLUSION}

The study showed significantly high level of contamination of soil and water due to fungal pathogens. This might be a reason for skin infections among the neighbouring community people.

\section{KEYWORDS}

Aspergillus, Microsporum, Dumping Yard, Leachate, Immunocompromised.

HOW TO CITE THIS ARTICLE: Vipinunni, Bernaitis L, Sabarianand et al. Pathogenic fungal contamination of municipal dumping yard, Kottayam and related health effects. J. Evolution Med. Dent. Sci. 2017;6(86):5964-5969, DOI: 10.14260/jemds/2017/1298

\section{BACKGROUND}

The agglomeration of solid waste is one of the common annoyances, especially in large populated developing countries like India. The lack of effective solid waste disposal system creates more complication among people, particularly for those who are living near the dumping yard. They have to face with many of pathogenic microorganisms, and several toxic substances. So solid wastes are now recognised as an important source of hazardous pollutants and that must be properly controlled.

'Financial or Other Competing Interest': None.

Submission 12-08-2017, Peer Review 13-10-2017,

Acceptance 19-10-2017, Published 26-10-2017.

Corresponding Author:

Dr. Vipinunni,

Lecturer,

Department of Microbiology,

RVS Dental College, Coimbatore.

E-mail: vipinshas@gmail.com

DOI: $10.14260 /$ jemds $/ 2017 / 1298$
Solid waste contains a heterogeneous conglomeration of diverse constituents, disposed of by our society. Municipal solid wastes are the products of residential, commercial and industrial sources, which includes newsprint, plastics, garden trimmings, cardboard, metals, food, textiles, furniture, glass, dead animals and so forth. ${ }^{1}$

Municipal solid waste is the subset of solid waste composed of a mixture of liquid, gases, solid and a small amount of hazardous waste. Economy of local population, time, and type of housing and home composting affects the amount of waste generation. ${ }^{2}$ Municipal solid waste landfills contain residential, commercial, industrial, non-hazardous sludge, construction and demolition debris and some industrial solid waste. ${ }^{3}$

The waste dumps are a common breeding ground for microbial pathogens; that a massive waste dump was an efficient, safe, economic method of solid waste was based on the supposition that such wastes are removed regularly and can be managed by a sole technique. ${ }^{4}$ Increased amount of plastic (2-20\%), metal (22\%), hazardous solvents $(0.3 \%)$, 
pesticides $(0.2 \%)$, and phenolic compounds are present in municipal solid waste. 5 Rapid urbanisation and unabated pollution of all sorts has led to the dumping of all wastes. Waste disposal is a serious problem everywhere and the easiest and conventional way of disposal is landfill or open dumping. The potential impact of dumping yard on environment and health is a matter of serious concern in recent years. ${ }^{6}$

The landfills are proved to be polluting the surface water in the adjoining area. Several health effects are documented among the residents near landfill sites. Adverse health effects like low birth weight, birth defects, certain type of cancers, allergies and some parasitic infections are reported. ${ }^{7}$

Fungi are ubiquitous and soil saprophytes often involved in various human ailments. Fungal diseases are emerging worldwide. It is well established that the rise in immunocompromised individuals and sudden drifts in the climate together with modern consumerist life style patterns are the major drivers of the emergence of fungal diseases. ${ }^{8}$

Many researchers also noticed the role of keratinophilic fungi in keratin degradation among waste dumps. However, the mycological health risks associated with dumping yard has not been much investigated, especially from developing countries where such sites are very common. ${ }^{9}$

The present study tries to expose the pathogenic threat posed by the dumping yard. The major objectives of the study are to analyse the possible mycological threat posed by the municipal dumping yard. The study focuses on a comparison of the fungal diversity among soil, leachate from dumping yard and drinking sources close to $(<100 \mathrm{~m}$ ) dumping yard.

The study also aims to assess the health status of interacting community in relation to the dumping yard.

\section{MATERIALS AND METHODS}

The descriptive study was conducted in order to find out the prevalent fungal pathogens in Municipal dumping yard soil, leachate and adjoining drinking water resources in Kottayam Municipal dumping yard at Vadavathoor. The study was conducted during April to June 2015.

A total of 50 soil samples from the dumping yard were collected once, before burning of the dump in the yard and a second sampling was conducted about one month after the first. Along with the second sampling, other samples such as leachate and water samples also were collected from neighbouring open wells (within $<100$ meters from dumping yard). Soil, leachate samples and drinking water were collected in sterile containers and transported immediately to the laboratory.

Approximately 10 grams of the samples were dispensed into sterile petri plates and Vanbreuseghem hair baiting technique was performed. ${ }^{10}$ The leachate was also processed in the same manner for fungal pathogens. The drinking water samples were filtered through $0.22 \mu \mathrm{m}$ Millipore filter and filter paper was inoculated into inhibitory mould agar (purchased from HiMedia (HM)-HM 246; lot no 0000005047). All the plates were incubated aerobically at room temperature for 20-25 days.

Soil and leachate samples with hair bait were subcultured after invasion and subsequent colonisation by the keratinophilic fungi. Subculture was done on Sabouraud dextrose agar (SDA) (from -HM 063; lot no WC030), and incubated for 10-15 days. Colonies with retarded growth were subcultured onto malt extract agar with $2 \%$ freshly drawn blood.

The sufficiently grown colonies were identified by performing scotch-tape method and by observing macroscopic (texture, topography, pigmentation, and exudates production) and microscopic (hyphal characters, conidiophores, conidial ornamentation) characteristics. ${ }^{11}$ Typical microscopic and macroscopic features were used for identification. The macroscopic features of the grown fungus are shown below in Figure 1 to 4. Photographic recording was also performed for both macroscopic and microscopic characteristics.

A detailed health survey was also conducted by questionnaire among the 55 residents around (within $<100$ metre) (using a structural interview sheet) the dumping yard. The obtained results were tabulated, analysed and discussed with available scientific literature.

\section{RESULTS}

An investigation on the prevalent fungal pathogens among different sources of the municipal dumping yard and surroundings was conducted. A survey on the socioeconomics and health of the neighbouring community was also conducted.

A total of seven fungal pathogens were isolated from soil samples of the dumping yard, with a high prevalence of Aspergillus flavus and related species (Table 1). The relative abundance of isolated fungal pathogens on the analysis shows that $49 \%$ isolates belonged to the Aspergillus genus; and the remaining $51 \%$ were almost equally shared by four other different species Geotrichum, Humicola, Microsporum and Rhizopus. The sampling was done for soil just before the burning process and just after a month of continuous burning.

The comparison on the pre-burning and post-burning period in relation to the prevalent fungal pathogens in the soil showed that all the major species present in the burning period were replaced with a new pathogenic community during the post-burning period except Aspergillus species (Table 2).

Similar fungi isolated from the leachate in the dumping yard fetched six species with a higher prevalence of Aspergillus fumigates and Aspergillus nidulans (Table 3). Among the isolates Aspergillus species formed $67 \%$ and the remaining 33\% was found by Geotrichum, Scedosporium, and Apophysomyces species equally.

The mycological evaluation of the drinking water resources near to the dumping yard $(<100$ metre) showed presence of twelve fungal pathogens (Table 4) with exceptionally high frequency of occurrence for Aspergillus fumigatus. The genus wise relative abundance showed as in other case that Aspergillus has the highest share (39\%)

The rate of isolation of fungal pathogen from three different sources showed significant differences and accordingly the highest rate of isolation was obtained from drinking water resources, as compared to leachate and the soil. A few species were found to be distributed in all the three sources; among them, Aspergillus fumigatus was more in water than soil and leachate; while Aspergillus flavus and Aspergillus nidulans were more in soil and leachate than in water. 
The socioeconomic and health survey of the neighbouring community of dumping yard, showed that $71.5 \%$ of the population have no job at all and $67 \%$ among them are economically poor class among 50 individuals. $38.1 \%$ of the respondents have skin infections and $1.8 \%$ of them have Squamous cell carcinoma. All the residents around the dumping yard are victimised with unending problem such as mosquito/fly menace, contaminations of well by wastes of birds and of foul smell (Table 5).

\section{DISCUSSION}

Population growth and economic development have brought increasing amounts of solid waste, and the quantity is increasing day by day. The disposal of waste in open landfill is the easiest method but it results in a series of adverse health effects to the interacting community including fringe area people. The leachate from landfill deteriorates the quality of the drinking water in the near vicinity. The relation between several vector borne diseases and waste dumping site are well established. ${ }^{12}$ However, studies on the possible role of Municipal dumping yard in the propagations of fungal pathogen are hardly ever explored. The present study has clearly demonstrated the severity of the situation, especially of microbiological threat. Samples such as soil, leachate and drinking water resources near the dumping yard were analyzed for fungal pathogen.

A total of seven fungal pathogens were isolated from the soil samples of dumping yard, represented by genus Aspergillus. Several reports are available in agreement with present finding.

Aspergillus species (Aspergillus niger, Aspergillus fumigatus, Aspergillus flavus) are commonly isolated from soil samples throughout the world, Ellis ${ }^{13}$ Al-Abdey et al(2001) and are capable of causing Aspergillosis in humans. ${ }^{14}$.

Absidia corymbifera, one of the saprophytic organism that is responsible for nosocomial infections isolated primarily from soil and decaying vegetation, and, Rhizopus species commonly isolated from the soil samples of Municipal dumping yard, particularly in India, Africa, Pakistan, Taiwan etc. ${ }^{15}$

Apophysomyces elegans, is the infrequent causative agent of zygomycosis, capable of causing cutaneous and subcutaneous infections, and have been isolated from soil in India. ${ }^{16}$

Ulfig et al, (1990) and Volz et al, (1995) detected the presence of Chrysosporium in poultry farm and feather dumping soil in India. Chrysosporium also isolated from hospital dust soil of public places. Dermatophytes like Microsporum nanum has been obtained from dumping yard soil. This shows that the dumping yard soil supports the growth of potential keratinophilic fungi.

Microsporum gypseum is frequently isolated from patients with dermatophytosis in Spain. ${ }^{17}$ Microsporum species was found to occur in the coal ash, heap soil in the landfill at Sosnowiec. ${ }^{18}$

Most of the keratinophilic fungal species isolated from municipal waste and waste contaminated environments are saprophytic (Microsporum species, Chrysosporium species) organisms rarely causing epidermal mycoses in human beings. ${ }^{19}$

Ulfig et al, (1996) isolated Chrysosporium species and Malbranchea species predominantly from a municipal landfill site. Geotrichum candidum, one of the fungi responsible for superficial infections of skin and nail has been recovered from soil, water samples in Philadelphia. ${ }^{20}$

In the present study, among the six fungal pathogens from the dumping yard leachate, four belonged to genus Aspergillus. Aspergillus is the most common fungal pathogen found everywhere and well recognised as economically, ecologically, medically important group. ${ }^{21}$ All the isolates of Aspergillus species in the present study are recognised as species of medical importance especially in immunocompromised patients. Interestingly, higher numbers of organisms (twelve) were obtained from the drinking water resources in the neighbouring area $(<100$ metre) of the landfill site than the soil, leachate samples of the dumping yard.

The presence of fungi like Aspergillus species, Chrysosporium species, Hormonema species and the dermatophyte Microsporum in drinking water is quite alarming. These are well recognised pathogens with varied pathognomonic features. ${ }^{22}$

Aslund (2006) has reported allergic and respiratory health affecting fungi resident in water from Sweden and Finland, enumerated 94 species of fungi from the collected 273 drinking water resources. ${ }^{23}$ Considering the lower sample size the present rate of isolation is much higher which poses substantial health threat to the community. ${ }^{24}$

Aspergillus species isolated from a study conducted in a Norway hospital (in water) were capable of causing human infections. ${ }^{25}$ Aspergillus species are one of the commonly isolated genera in water, causing opportunistic invasive infection, isolated from potable water in Finland and constitute potential hazard to the community. ${ }^{26}$

Aspergillus fumigates has been one of the most significant fungal pathogen causing health problems over the last decades. Studies of route of transmission are increasingly providing further evidence of the existence of the water source thereby. ${ }^{27}$

Aspergillus species, Penicillium species, Gliocladium species are isolated from Palan river in Tamil Nadu, from different water sources including hot water, cold water, and found that Aspergillus fumigates is the major thermophilic fungal pathogen isolated. ${ }^{28}$

The comparison of the present rate of fungal isolation from different sources of Municipal dumping yard revealed highest isolation of Aspergillus growth obtained from drinking water (p:008) followed by the soil and leachate (p:003). This shows that though the pathogen diversity is expected in high number in soil and leachate, the optimum environment may be available in drinking water resources though the leachate makes the well as their breeding ground. Savitz and Weber (2006) reported that landfill leachate escaping into the groundwater would put the residents nearby at greatest risk of the potential infections. ${ }^{29}$

A comparison on the pathogenic diversity of the dumping yard before and after the burning process showed that the fungal diversity has been significantly changed in the postburning period except in the case of Aspergillus. This means that the environmental factors have a significant role in determining the diversity of fungal pathogen. It is well established that fungal distribution patterns mainly depend upon the type of soil and other factors such as human or animal interacting including diverse type of pollutions. ${ }^{30}$ 
Several reports suppose the current finding that polluted soil and contaminated water resources may have higher population density and diversity of fungal pathogens. However, with rise in immunocompromised cases, in recent years, fungal infections have become a serious public health issue. Besides, several mycoses have been recognised as emerging infections (WHO:2007). Hence, the present isolation of potential mycotic agents, from dumping waste sources, soil and leachate of dumping yard is of high significance. ${ }^{31}$

\section{CONCLUSION}

The present study showed significantly high level of contamination of soil and water due to fungal pathogens. This might be a reason for skin infections among the neighbouring community people. Conventionally, fungal pathogens are considered as of least importance as they are causing mostly mild infections and fatal incidences are comparatively rare. Though the study is limited to a small sample size and short span of study period, the data is significant, both for academic and public health points of view.

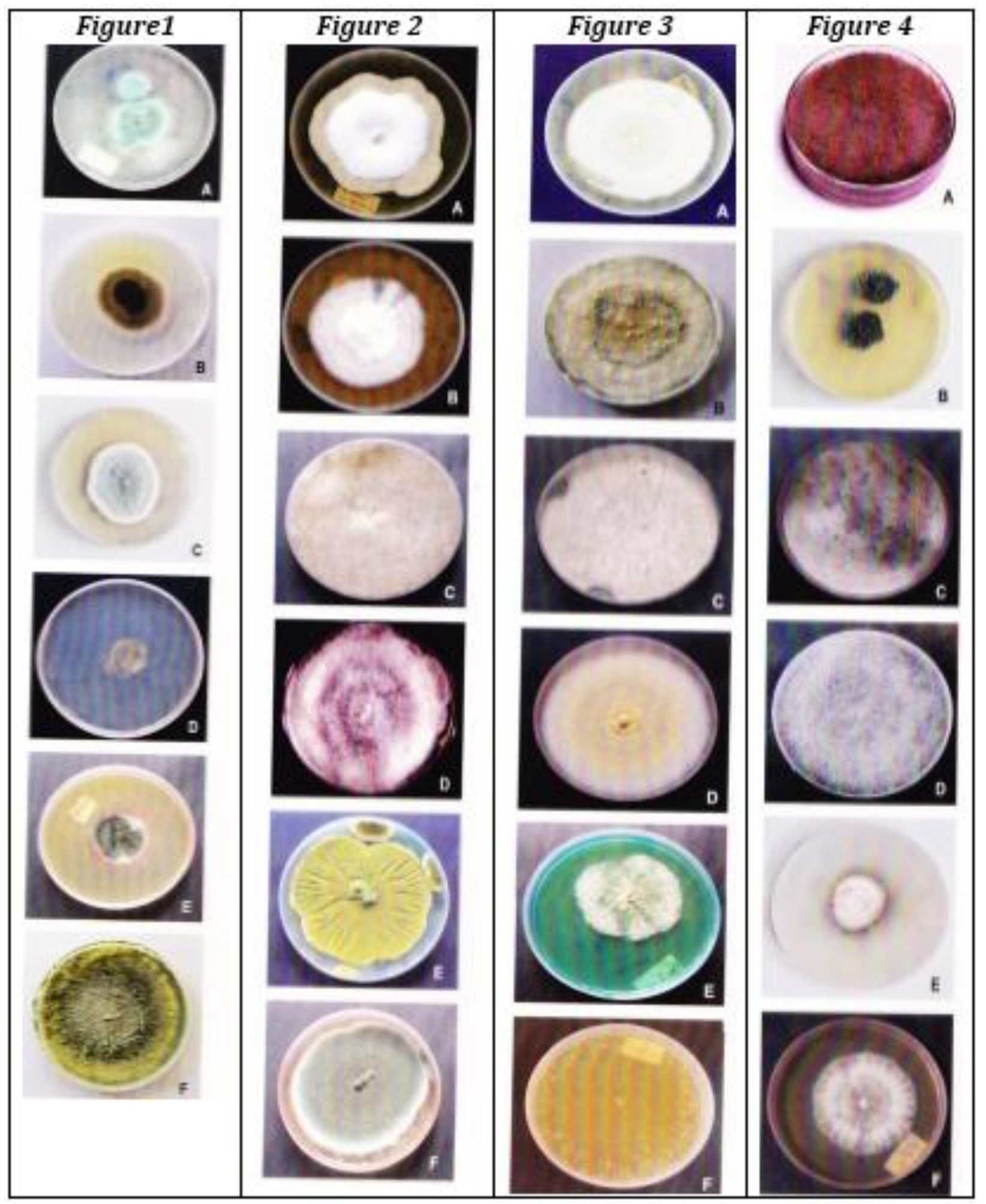




\begin{tabular}{|c|c|}
\hline Figure $1(\mathrm{~A})$ & $\begin{array}{c}\text { Microsporum audouinii on Sabouraud dextrose } \\
\text { agar (SDA) after ten days of incubation }\end{array}$ \\
\hline Figu & \begin{tabular}{|c|}
$\begin{array}{c}\text { Microsporum nanum on Malt extract agar after } \\
\text { eight days of incubation. }\end{array}$ \\
\end{tabular} \\
\hline Figure 1(C) & $\begin{array}{c}\text { Absidia corymbifera on SDA after seven days of } \\
\text { incubation }\end{array}$ \\
\hline Figure & $\begin{array}{r}\begin{array}{r}\text { Apophysomyces elega } \\
\text { of in }\end{array} \\
\end{array}$ \\
\hline Figu & $\begin{array}{r}\text { Aspergillus flavus } \\
\text { inc }\end{array}$ \\
\hline Figure 1(F) & $\begin{array}{r}\text { Aspergillus fumigat } \\
\text { in }\end{array}$ \\
\hline Figu & $\begin{array}{r}\text { Aspergillus nidular } \\
\text { in }\end{array}$ \\
\hline Figur & $\begin{array}{r}\text { Aspergillus niger } \\
\text { in }\end{array}$ \\
\hline Figure 2(C) & $\begin{array}{r}\text { Aspergillus penicilli } \\
\text { of }\end{array}$ \\
\hline $\mathrm{F}$ & $\begin{array}{r}\text { Aspergillus ustus } \\
\text { ir }\end{array}$ \\
\hline Figu & $\begin{array}{r}\text { Chaetomium atrob } \\
\text { days }\end{array}$ \\
\hline Figl & $\begin{array}{r}\text { Chrysosporium } \\
\text { il }\end{array}$ \\
\hline $\mathrm{Fi} \xi$ & $\begin{array}{r}\text { Geotrichum candidu } \\
\text { of }\end{array}$ \\
\hline & Gliocladium on SDA \\
\hline Figur & $\begin{array}{r}\text { Hormone } \\
\mathrm{a}\end{array}$ \\
\hline & Humicola \\
\hline Figu & $\begin{array}{r}\text { Malbranchea } 0 \\
\mathrm{~d}\end{array}$ \\
\hline Figu & $\begin{array}{r}\text { Monocillium on SD } \\
\text { inc }\end{array}$ \\
\hline $\mathrm{F}$ & $\begin{array}{r}\text { Mucor circinelloid } \\
\text { in }\end{array}$ \\
\hline Figu & $\begin{array}{l}\text { DA after ten days of } \\
\text { on }\end{array}$ \\
\hline Figu & $\begin{array}{l}\text { Phialemonium obovotum on Malt extract agar } \\
\text { after nine days of incubation }\end{array}$ \\
\hline $\mathrm{Fi}$ & $\begin{array}{r}\text { Rhizopus stolonifer } 0 \\
\text { inct }\end{array}$ \\
\hline Figure 4(E) & $\begin{array}{r}\begin{array}{r}\text { Scedosporium prolific } \\
\text { of in }\end{array} \\
\end{array}$ \\
\hline & Sepedonium on S \\
\hline
\end{tabular}

\begin{tabular}{|c|c|c|}
\hline Sl. No. & Fungal Pathogens & $\begin{array}{c}\text { Frequency of } \\
\text { Occurrence (\%) }\end{array}$ \\
\hline 1 & Aspergillus flavus & 20 \\
\hline 2 & Aspergillus fumigatus & 10 \\
\hline 3 & Aspergillus ustus & 10 \\
\hline 4 & Geotrichum candidum & 10 \\
\hline 5 & Humicola species & 10 \\
\hline 6 & Microsporum nanum & 10 \\
\hline 7 & Rhizopus stolonifer & 10 \\
\hline \multicolumn{2}{|c|}{ Table 1. List of Fungal Pathogens Isolated from Soil } \\
Samples in the Dumping Yard During Pre-burning Period \\
\hline
\end{tabular}

\begin{tabular}{|c|c|c|}
\hline Sl. No. & Fungal Pathogens & $\begin{array}{c}\text { Frequency of } \\
\text { 0ccurrence (\%) }\end{array}$ \\
\hline 1 & Absidia corymbifera & 5 \\
\hline 2 & Aspergillus flavus & 60 \\
\hline 3 & Aspergillus niger & 5 \\
\hline
\end{tabular}

\begin{tabular}{|c|c|c|}
\hline 4 & Mucor circinelloides & 5 \\
\hline 5 & Aspergillus penicillioides & 5 \\
\hline 6 & Phialemonium obovotum & 10 \\
\hline 7 & Rhizopus stolonifer & 5 \\
\hline \multicolumn{2}{|c|}{ Table 2. List of Fungal Pathogens Isolated from Soil } \\
Samples in the Dumping Yard During Post-burning Period \\
\hline
\end{tabular}

\begin{tabular}{|c|c|c|}
\hline Sl. No. & Fungal Pathogens & $\begin{array}{c}\text { Frequency of } \\
\text { 0ccurrence (\%) }\end{array}$ \\
\hline 1 & Apophysomyces elegans & 10 \\
\hline 2 & Aspergillus flavus & 10 \\
\hline 3 & Aspergillus fumigates & 20 \\
\hline 4 & Aspergillus nidulans & 20 \\
\hline 5 & Geotrichum candidum & 10 \\
\hline 6 & Scedosporium prolificans & 10 \\
\hline
\end{tabular}

Table 3. List of Fungal Pathogens Isolated from Leachate Samples in the Dumping Yard during Post-Burning Period

\begin{tabular}{|c|c|c|}
\hline Sl. No. & Fungal Pathogens & $\begin{array}{c}\text { Frequency of } \\
\text { Occurrence (\%) }\end{array}$ \\
\hline 1 & Aspergillus fumigatus & 26.66 \\
\hline 2 & Aspergillus nidulans & 6.66 \\
\hline 3 & Aspergillus niger & 6.66 \\
\hline 4 & Chaetomium atrobrunneum & 6.66 \\
\hline 5 & Chrysosporium & 6.66 \\
\hline 6 & Gliocladium & 6.66 \\
\hline 7 & Hormonema dematioides & 13.33 \\
\hline 8 & Malbranchea & 6.66 \\
\hline 9 & Microsporum audouinii & 6.66 \\
\hline 10 & Monocillium & 6.66 \\
\hline 11 & Penicillium verrucosum & 6.66 \\
\hline 12 & Sepedonium & 6.66 \\
\hline
\end{tabular}

Table 4. List of Fungal Pathogens Isolated from Drinking Water Resources near to the Dumping Yard during Postburning Period

\begin{tabular}{|c|c|c|c|c|}
\hline I & Social & Parameter & Number & Percentage \\
\hline & \multirow{2}{*}{ Sex wise } & Male & 22 & 40 \\
\hline & & Female & 33 & 60 \\
\hline & \multirow{3}{*}{ Age wise } & $0-25$ & 20 & 36.36 \\
\hline & & $26-50$ & 21 & 38.18 \\
\hline & & $51-75$ & 14 & 25.45 \\
\hline & \multirow{5}{*}{ Occupation } & No job & 39 & 70.91 \\
\hline & & Coolie & 4 & 07.27 \\
\hline & & Business & 3 & 05.45 \\
\hline & & Student & 5 & 09.09 \\
\hline & & Others & 4 & 07.27 \\
\hline & \multirow{3}{*}{$\begin{array}{c}\text { Economic } \\
\text { Status }\end{array}$} & Poor & 37 & 67.27 \\
\hline & & Moderate & 18 & 32.73 \\
\hline & & Rich & Zero & Zero \\
\hline II & \multicolumn{4}{|c|}{ Health } \\
\hline & \multirow{5}{*}{$\begin{array}{l}\text { Acute Diseases } \\
\text { (During the } \\
\text { Past One Year) }\end{array}$} & Skin infections & 21 & 38.18 \\
\hline & & Allergy & 7 & 12.73 \\
\hline & & $\begin{array}{l}\text { Breathing } \\
\text { problem }\end{array}$ & 5 & 09.09 \\
\hline & & Fever & 5 & 09.09 \\
\hline & & Diarrhoea & 2 & 03.64 \\
\hline & Chronic & Cancer & 1 & 01.82 \\
\hline
\end{tabular}




\begin{tabular}{|c|c|c|c|c|}
\hline & Disease & & & \\
\hline III & Sanitation & $\begin{array}{c}\text { Near to toilet- } \\
\text { yes }\end{array}$ & 1 & 01.82 \\
\hline & Open Well & No & 54 & 98.18 \\
\hline $\begin{array}{c}\text { Drinking } \\
\text { Water (Boiling) }\end{array}$ & Yes & 55 & 100 \\
\hline \multirow{4}{*}{$\begin{array}{c}\text { Problems } \\
\text { Posed by } \\
\text { Dumping Yard }\end{array}$} & $\begin{array}{c}\text { Mosquito/fly } \\
\text { menace }\end{array}$ & 55 & 100 \\
\cline { 2 - 5 } & $\begin{array}{c}\text { Foul smell } \\
\text { of well by } \\
\text { wastes (by } \\
\text { birds) }\end{array}$ & 55 & 100 \\
\hline \multicolumn{4}{|c|}{$\begin{array}{c}\text { Table 5. Data on Socioeconomic and Health } \\
\text { Survey on the Neighbouring Community of } \\
\text { Kottayam Municipal Dumping Yard }\end{array}$} \\
\hline \multicolumn{4}{|c|}{}
\end{tabular}

\section{REFERENCES}

[1] Stone R. Disposal of sewage sludge into a sanitary landfill. Environmental protection agency sw71. d. Encyclopedia of Life Support Systems 1974.

[2] Bramfield R, Wasser DH, Valdes A. Waste characterisation study: assessment of recyclable and hazardous components in Mento Park. Br Journ 2000;18:131-6.

[3] Ulfig K, Terakowski M, Lukasik W. A preliminary study on the occurrence of keratinophilic fungi in the street sweepings from Charzow. Rocxihiki PZH 1996;47(2):143-9.

[4] Achudume AC, Olawale JT. Microbial pathogens of public health significance in waste dumps and common sites. J Environ Biol 2007;28(1):151-4.

[5] Franklin A. Characterization of municipal solid waste in U.S. Br Journ 1991;50:653-7.

[6] Abdullah KH, Visset MF, Korcz M, et al. Taxonomy study of Keratinophili fungi isolated from soil and some mammals in France. Mycopathologia 1995;101:133-40.

[7] Morris RD, Naumova EN, Levin R, et al. Temporal variation in drinking water turbidity and diagnosed gastroenteritis in Milwaukee. Am J Public Health 1996;86(2):237-9.

[8] Nicod LP, Pache JC, Howarth N. Fungal infections in transplant recipients. Eur Respir J 2001;17:133-40.

[9] Ahern M. Water and health. A world water crisis. Environmental Epidemiology 2006:109-24.

[10] Strauss E, King W, Arthur L, et al. A study of drinking water among children in Philippines. BMC Public Health 2000;1:8.

[11] Gummowski AN, Ellabid MS, Jillson FL. Chronic asthma due to dermatophytes. J Soc Occup Med 1996;41:1259.

[12] Vanbreuseghem R. Technique biologic, isolementdes dermatophytesdee soln. Ann Soc Belg Med 1952;32:173-8.
[13] Ellis ME, Al-Abdely $\mathrm{H}$, Sandridge A, et al. Fungal endocarditis: evidence in the world literature, 19651995. Clin Infect Dis 2001;32(1):50-62.

[14] Denning DW. Invasive aspergillosis. Clin Infect Dis 1998;26(4):781-803.

[15] Sundaram BM. Incidence of keratinophilic fungi in rice field soils. Mycopathologia 1987;97:43-4.

[16] James. Ultra structural aspects of demolition of human hair in vitro by Chrysosporium tropicum. Mycoses 1998;34:154-65.

[17] Farrow WM. Tropical soil fungi. Mycologia 1954;46(5):632-46.

[18] Marshall MM. Dermatophytosis due to Microsporum gypseum reports of eight cases. Rev Inbervam Mycol 2004;21(3):147-9.

[19] Anderson RF. Solid waste and public health. In: Greenberg. edr. Public health and the environment. The United States experience: New York: Guildford Publishers 1987:495-952.

[20] Klich. Opportunistic fungal infections: a major problem in immunocompromised patients. Aspergillus Updates Medicine 2002;79:281-2.

[21] Cheng KKJ, Bennet JE. Medical mycology. Philadelphia: Lea and Febiger 1992:105-61.

[22] Asan A. Check list of Aspergillus and Penicillium species reported from Tarkey. Turk J Bot 2000;24:151-67.

[23] Hageskal G, Knutsen AK, Gaustad P, et al. Diversity and significance of mold species in Norwegian drinking water. Appl Environ Microbiol 2006;72(12):7586-93.

[24] Simpanya MF. Dermatophytes: their taxonomy, ecology and pathogenicity. In: Kushwaha RKS, Guarro J. eds. Biology of dermatophytes and other Keratinophilic fungi. Revista Iberoamericana de Micologia, Bilbao 2000:1-92.

[25] Sundaram. A comparison of fungi from polluted water. Environ Pollute 1987;35:57.

[26] Warris A, Gaustad P, Meis JF, et al. Recovery of filamentous fungi from water in a paediatric bone marrow transplantation unit. J Hosp Infect 2001;47(2):143-8.

[27] Aslund P. Hudirritasjon erforosakadeavmik rowampar. Varfoda 1984;36:327-36.

[28] Anaissie EJ, Stratton SL, Dignani MC, et al. Pathogenic molds (including Aspergillus species) in hospital water distribution systems: a three-year prospective study and clinical implications for patients with hematologic malignancies. Blood 2003;101:2542-6.

[29] Savitz A, Weber K. The triple bottom line: How today's best-run organizations are achieving economic, social and environmental success - and how you can too. San Francisco: Jossey Bass 2006.

[30] Rippon JW. Medical mycology. The pathological fungi and actinomycetes. $3^{\text {rd }}$ edn. Philadelphia: WB Saunders Company 1988:127-53.

[31] Hafezall A, Sharowny EHMM. Kertinolytic and keratinophilic fungi in soil. J Basic Microbial 1997;30: 73-9. 